\title{
GCU
}

Glasgow Caledonian

University

University for the Common Good

\section{Who banned the war game? A fifty year controversy reassessed}

Cook, John R.

Published in:

Journal of British Cinema and Television

DOI:

10.3366/jbctv.2017.0351

Publication date:

2017

Document Version

Author accepted manuscript

Link to publication in ResearchOnline

Citation for published version (Harvard):

Cook, JR 2017, 'Who banned the war game? A fifty year controversy reassessed', Journal of British Cinema and Television, vol. 14, no. 1, pp. 39-63. https://doi.org/10.3366/jbctv.2017.0351

\section{General rights}

Copyright and moral rights for the publications made accessible in the public portal are retained by the authors and/or other copyright owners and it is a condition of accessing publications that users recognise and abide by the legal requirements associated with these rights.

Take down policy

If you believe that this document breaches copyright please view our takedown policy at https://edshare.gcu.ac.uk/id/eprint/5179 for details of how to contact us. 
'Who banned The War Game ?' : A Fifty Year Controversy Reassessed

John R. Cook

Introduction

It is now over fifty years since Peter Watkins' famous nuclear film, The War Game, was banned from TV amidst a veritable firestorm of controversy. The furore around its censorship helped elevate it into one of the iconic films of the 1960s, particularly when, after being granted a limited cinema release in 1966, the film went on to win an Oscar in Hollywood for 'Best Documentary Feature'. ${ }^{1}$ This was much to the chagrin of the BBC which had commissioned and produced it but in November 1965 announced it had taken the decision not to show it on TV, ostensibly on the grounds that Watkins' carefully researched documentary dramatisation of what might happen if a nuclear attack occurred on British soil was too 'horrifying for the medium of broadcasting'. At the time of its announcement, the BBC went out of its way to stress this was a decision it had taken on its own and 'not as a result of outside pressure of any kind'. ${ }^{2}$ But when it emerged that prior to announcing the ban, the Corporation had invited officials from the Cabinet Office, Ministries of Defence and Home Office to preview it to gauge their opinion on whether or not it should be shown to the public, The War Game became a cause célèbre. Watkins had resigned from the BBC protesting the $B B C$ 's traditional independence from Government had been violated. ${ }^{3}$ Questions were asked in the House of Commons while organisations like CND began to use the film as a campaigning tool, arguing the film exposed the terrible truth about the possession and use of nuclear weapons which the powers that be wished to keep from the TV-watching masses.

The dramatic 'fall-out' from the censorship of The War Game has continued to reverberate down the years. Watkins' career never recovered from the furore and in 1968 , he quit the UK for permanent self-exile abroad, claiming the atmosphere in Britain had become inimical to his work 
simply because he had made The War Game and fought so hard for it to be shown to a mass TV audience. Despite a distribution deal having been struck between the BBC and the British Film Institute in 1966 to handle a limited cinema release and all requests for private screenings, it was not until July 1985 that the BBC, as the film's legal owner, lifted its worldwide ban on TV showings, first screening The War Game as part of a BBC-2 season of programmes marking the fortieth anniversary of the dropping of the atomic bombs on Hiroshima and Nagasaki. By then, The War Game had become a totemic film for the Left. The ending of détente and ramping up of the Cold War during the first years of Ronald Reagan's presidency had made nuclear weapons a key public issue again in the early 1980 s and throughout this period, the film continued to do a brisk trade in rentals by CND and others for screenings in public halls, schools and other gatherings.

In 1980, The War Game controversy itself was revisited when Michael Tracey in an article for The Guardian newspaper argued that BBC papers he had seen whilst researching the authorised biography of Sir Hugh Greene seemed to point to Lord Normanbrook, the Chairman of the BBC's Board of Governors, as having played the key role in the banning of the film. ${ }^{4}$ Normanbrook was a former Cabinet Secretary who in the 1950s and early 1960s had been at the heart of secret Government planning for Britain in the event of nuclear war, extrapolating post-attack scenarios of a kind very similar to those envisaged and critiqued by Watkins in The War Game. Greene was the BBC's Director-General of the 1960s with a famous reputation for liberalism. The actions of Greene in banning the film seemed out of character for Tracey, therefore suggesting Normanbrook as the prime mover. In a follow-up letter to The Guardian, Greene, however, denied this and right up until his death in 1987 stuck to the official BBC line that the decision not to show the film was his alone as Editor-in-Chief of the Corporation's output. ${ }^{5}$

Notwithstanding Greene's denial, suspicion has continued to dog the film up to this present day. 
Who exactly banned The War Game from TV ? Was it the BBC's decision alone or was the British Government deeply implicated and the BBC's traditional independence from Government violated in 1965 , as Watkins always claimed ? The controversy rumbles on. In 2015 , to mark the fiftieth anniversary of the film, BBC Radio 4 broadcast The War Game Files - an independently produced radio documentary, narrated by the film director Michael Apted, which took a fresh look at the fifty year controversy. ${ }^{6}$ Utilising new research by me into previously classified Cabinet Office files, it argued that the role of HM Government in censoring the film was more extensive than had been admitted at the time and that the official reason given for banning the film from TV - 'too horrifying for the medium of broadcasting' - belied far more profound concerns which went to the very heart of the British nuclear state during the Cold War era.

This present article builds upon my recent research for the radio documentary, drawing upon the Cabinet Office files that formed the basis of the programme and disseminating these findings in more detail within an academic journal context. Reviewing the extant evidence surrounding the controversy, its aim is to take a fresh look at the old question of 'who banned The War Game?'

In writing about the film, one inevitably enters into dialogue with the work of previous scholars. In recent years, Murphy (2003), Chapman (2006) and Shaw (2006), amongst others, have all examined The War Game controversy in some detail. ${ }^{7}$ Taking their cue from Michael Tracey, they have tended to start with the BBC files at the Written Archives, Caversham which holds extensive documentation on the film. But as Tracey pointed out as far back as 1982, the problem with the $\mathrm{BBC}$ archives is that after a certain point, the trail goes cold: there appears to be no written record within the BBC files as to 'who made the specific decision [not to show the film] and what the arguments for making it actually were' (Tracey, 1982: 52). 
This article therefore adopts a different approach. Instead of the BBC files which have been extensively investigated in the past, the article reverses perspective and concentrates on how the film was discussed and considered within Whitehall by both civil servants and Government ministers. While previous scholars such as Chapman, Murphy and Shaw have certainly examined Government files as part of their overall research, they have tended not to explore them in nearly as much detail as here, meaning the full content and implications of HM Government's 'The War Game Files' have perhaps not yet been fully elucidated for an academic readership.

Utilising, therefore, all-new archival research, below and throughout, from the National Archives at Kew, the aim of the present article is to disseminate, for the first time, a much fuller picture of Government and Whitehall's involvement in the TV banning of The War Game, going into a level of detail in terms of exposition and citation of relevant Government memos far greater than has been attempted before. In so doing, the article sets out to reveal new evidence, interpretations and theories which aim to offer a comprehensive reassessment and fresh explanation of the fifty year old controversy of who banned The War Game from TV and why.

\section{The War Game comes to Whitehall}

CAB21/5808 is the key folder amongst the mass of official files in The National Archives relating to The War Game. ${ }^{8}$ Scribbled on its front cover in pencil is 'HMG Censorship of The War Game' - a legend guaranteed to induce a sharp intake of breath in any researcher familiar with the controversy, though who wrote these words and for what reason remains unknown. Inside is a mass of declassified Cabinet Office papers, some marked 'SECRET' or 'TOP SECRET', which contains correspondence either written from or received by officials working in the Cabinet Office in the autumn of 1965 during the period of Harold Wilson's Labour Government (1964-70). Sorting this jumble of files into date-order allows us to reconstruct the timeline of interactions between civil 
servants, Government ministers and the most senior management of the BBC that ultimately led to the public announcement of the banning of The War Game from TV on 26 November 1965.

The 'problem' of The War Game first surfaces for Government not from the BBC but from a rather more idiosyncratic source. On 7 September 1965, Derek Mitchell, Principal Private Secretary to Harold Wilson, wrote to various Government departments, including the Ministries of Defence and the Home Office, to alert them that the famous co-founder of the 'Clean-Up TV Campaign', Mrs Mary Whitehouse, had written personally to the Prime Minister about The War Game. Mrs Whitehouse had seen an article in the Sunday Express of 5 September which had quoted $\mathrm{Mr}$ Leonard Lozman, a Civil Defence Officer from Tonbridge, Kent. ${ }^{9}$ Tonbridge had been one of the Kent locations where Watkins' film had been shot with the help of the local police and fire brigade and Lozman had provided technical advice. Thus he had advance knowledge of the subject of the film. Quoting Lozman's reported view that the film, when screened, would “'have a terrible effect on the public morale"', Mrs Whitehouse submitted in her letter to the Prime Minister that:

the decision as to whether or not this film should be shown is one which should be taken by the Home Office and not the BBC...

... This programme could have a serious effect upon the morale of people at home, and, should it later be shown abroad, upon the image of the British public throughout the world. $^{10}$

As Mitchell noted in his memo to Government colleagues, Mrs Whitehouse's letter raised 'some awkward points affecting relations between Government and the broadcasting authorities and has some major political overtones'. Of most concern was that Mrs Whitehouse had sent similar letters to the leaders of the Conservative Opposition and Liberal Party alongside other politicians 
and that The War Game had already come to the attention of the press. In Mitchell's words, this meant the matter needed 'to be gripped pretty fast and at a high level' ${ }^{11}$

Image, even in this era before our own one of political 'spin', was clearly everything and this was potentially embarrassing for Government because that very day, the BBC's Chairman, Lord Normanbrook - unaware at that point of Whitehouse's letter to the Prime Minister or indeed any reference to the film in that week's press - had taken the crucial step of alerting Whitehall to The War Game. The way he did this tells us much about the close regular contact between the most senior management of the $\mathrm{BBC}$ and Whitehall during this period and the frequently informal manner in which it was conducted. As the former Secretary of the Cabinet Office, Normanbrook approached his successor, Sir Burke Trend, for 'conversations'. ${ }^{12}$

In the first of these, Normanbrook informed Trend that the BBC had made The War Game and that it was a film, which 'in Normanbrook's view, ought to be looked at by the Government before any final decision was taken by the BBC to show it on television'. Trend's Private Secretary Bill Mclndoe recorded the BBC Chairman's view that 'the film was apparently unnerving in parts' and that 'Normanbrook appeared to entertain some personal doubt about whether it was right to show it'. At any rate, 'he was clear that it should not be shown without some prior reference to the Government'. The BBC Chair agreed to write a formal letter to Trend, copied to the Home Office, suggesting that 'two or three officials in the Departments principally concerned might gather together in order to view the film at some convenient place and time'. ${ }^{13}$

This is the origin of the process which led to the highly controversial previewing of the film by officials from the Home Office, Ministry of Defence and Post Office together with Trend himself, which took place at BBC Television Centre on 24 September 1965 and against which Watkins made 
strong protests, further stoking the flames of public controversy. The day after his conversation of September 6 with Trend, Normanbrook followed up with a telephone call to Trend's Private Secretary to ask him to relay to Trend that he had now found out about Mrs Whitehouse's letter to the Prime Minister. Normanbrook's reaction was significant. Though Whitehouse's interventions were 'much to the surfeit of the $B B C$ ', Normanbrook was keen that Mclndoe relay to Trend and in turn to No. 10 that 'the substance of the point which she appeared to be making, however, that a film such as The War Game should not be televised without Government approval, was one which the BBC, in the person of Normanbrook, had already taken' ${ }^{14}$ Normanbrook then followed up with a letter directly to Trend to affirm that the BBC had now issued guidance to its staff in dealing with any press enquiries prompted by Whitehouse's letter and its embarrassing timing both for BBC and Government - namely that while the BBC could 'not understand how Mrs Whitehouse is involved in this (her Campaign is concerned with morals, not with such matters as defence policy)', nevertheless the BBC wished to make it clear that "decisions on such matters are taken at the highest level in the BBC after appropriate consultations, and take full account of public policy"', ${ }^{15}$

Here, then, we have an acknowledgement in writing by the Chairman of the BBC Board of Governors that the film was referred to Government for 'approval' (in a highly unusual move seemingly at odds with the BBC's traditional independence from Government) not because it was judged too 'horrifying for the medium of broadcasting' as expressed in the BBC's later announcement to the public, but for reasons of 'defence policy'. In memos both within the BBC and in Whitehall, the euphemism frequently used for this is 'public policy', as above. Embarrassingly for both BBC and Government, Mrs Whitehouse, in her ill-timed letter, had already explicitly voiced the reason why the film might be thought to be a defence policy issue: namely the fear that its televising could have 'a terrible effect on the public morale'; Watkins' harrowing 
portrayal of the devastation of nuclear attack on the UK might cause considerable distress and a defeatist attitude amongst the mass TV-watching public which in turn could give a potential tactical advantage to the Soviets in the Cold War.

The personal involvement of Normanbrook in referring the film to Government may seem to lend credence to Tracey's conclusions that this meant the liberal Director-General, Hugh Greene, was largely 'bounced' into uncharacteristic censorship of The War Game due to the determined actions of his Chair: the former Cabinet Secretary, Normanbrook, who still seemed to be operating within the mindset of a civil servant rather than a public service broadcasting official. Such a view, however, is somewhat troubled by a memo written the next day, 8 September 1965 , and addressed to Derek Mitchell, Harold Wilson's Private Secretary. This was from Dennis Trevelyan, Private Secretary to the Lord President of Council - that is, to the leader of the House of Commons, Labour MP Herbert Bowden. ${ }^{16}$ In this, Trevelyan reported a luncheon Bowden had had that day at which both Greene and Normanbrook were present. Bowden had taken the opportunity to raise the matter of The War Game with both men.

Trevelyan's report of the conversation indicated that Normanbrook was 'fully apprised of the embarrassment which could be caused if it were made to appear that the Government are implicated in the decision whether or not the film should be shown'. Yet, as reported by Trevelyan, the conversation went further:

If, as Lord Normanbrook and Sir Hugh Greene undoubtedly assume, the conclusion were to be reached that the film should not be shown, Sir Hugh Greene said that he would be prepared to issue a press statement to the effect that the $\mathrm{BBC}$ itself had decided that it would be against the public interest for the film to be shown. 
If this were to be the outcome, Trevelyan noted, 'it would undoubtedly go some way towards preventing embarrassment which would be caused if the Government were known to be implicated in the decision'. Trevelyan also contemplated the alternative, though significantly he put this only in parentheses: 'If officials and the BBC reach a contrary conclusion - that the film should be shown - then it will be for Ministers to consider the matter and the possibility may arise of the Government intervening in some way)'. Pointedly, however, he ended: '(But there is no need to consider this possibility, with its serious political implications, at the moment)' ${ }^{17}$

Hence here we have the Director-General of the BBC secretly agreeing with a senior member of the Government to put out a press statement giving the false impression the BBC had acted independently should, as both he and Normanbrook actively assumed, Whitehall officials advise against showing the film. And on 26 November 1965, this was exactly what the BBC did, releasing a statement to the press that the decision not to televise The War Game was 'the BBC's own decision... taken after a good deal of thought and discussion, but not as a result of outside pressure of any kind' ${ }^{18}$

How could a Director-General like Sir Hugh Greene, one with such an apparently liberal reputation, allow the traditional independence of the $\mathrm{BBC}$ to be so heavily compromised in this way ? To understand this, one has to consider, briefly, the backgrounds of the men at the very top of the BBC to whom the decision whether or not to screen The War Game had been referred internally.

\section{The limits of liberalism}

It is important to remember this was only twenty years after the end of the Second World War when the BBC had taken explicit direction from the Ministry of Information and operated as a 
'fourth arm' of the British war effort. ${ }^{19}$ The ethos of Whitehall was arguably still embedded within the senior echelons of the BBC during the Cold War years. Indeed there was something of a revolving door at this time whereby senior civil servants would later move on to top management roles within the Corporation. Normanbrook's status as a former Whitehall senior official was far from unusual in this respect. For example, Greene's immediate predecessor as Director-General, Sir Ian Jacob, had served as Military Assistant Secretary to Winston Churchill's Cabinet during the Second World War whilst Sir Alexander Cadogan, the Chairman of the Board of Governors for the majority of Jacob's tenure as Director-General (1952-7), had been a permanent under-secretary at the Foreign Office between 1938 and 1946 (Miall, 1994: 91).

That this should be so through the 1950s and early 1960s becomes less surprising when considered against the historical backdrop. With the Cold War at its 'hottest' during these years, the wartime mentality of broadcasting as a 'fourth arm' requiring close, trusted liaisons with Whitehall not only persisted but arguably flourished in this period. Broadcasting had been recognised as a potent means of delivering anti-communist propaganda abroad (Nelson 1997; Webb 2014) and it is noteworthy that both of the Director-Generals who served during this period had had strong track records of leadership in overseas broadcasting. Prior to taking up his appointment as Director-General in 1952, Sir lan Jacob had served as Head of the BBC's European and Overseas Services in the late 1940s. His successor and protégé, Greene, despite the liberal reputation he would later come to be remembered for in the 1960s, also forged his management career in the early years of the Cold War. In 1949, Jacob had appointed him Head of the BBC's Russian and East European Services, broadcasting to behind the Iron Curtain. Subsequently, Greene was invited by the British Government to lead its campaign of psychological warfare against communist insurgents in Malaya in the early 1950s (Tracey, 1983: 118; 126). ${ }^{20}$ 
Hence while Greene may have tended towards liberalism on social and cultural questions, when it came to the larger issue of Soviet Communism and the potential threat posed by it to those freedoms of the West he cherished, he was much more of a Cold Warrior. A contribution by him to the BBC's Year Book of 1951, written when he was still Head of the Russian and East European Services, illustrates this point well. Describing the BBC's radio broadcasts to the East European satellite states of the Soviet Union, Greene outlined the objective as being to reach 'millions of enemies of Communism whose faith we have to sustain; some Communists whose doubts we can foster' (Greene, 1950: 12). For those broadcasts aimed at the Soviet Union itself, one of the principal aims was to provide 'accounts of what liberty really means and of the fundamental qualities of the Western way of life' (Greene, 1950: 13).

Given such a Cold War and anti-communist broadcasting background, Greene would have been sensitive to any $B B C$ project potentially undermining of the West's ongoing struggle against the Soviet Union and from the very outset of The War Game's production, the Director-General had worried Watkins might inadvertently disclose 'classified information' (Shaw, 2006: 1359). There is little hard evidence that throughout the whole process of considering whether The War Game should be shown on television, Greene was in any way out of step with his Chair, Lord Normanbrook. Both appeared to act together and in concert every step of the way. ${ }^{21}$

Certainly, it was Watkins' great misfortune that Lord Normanbrook was Chair of the BBC Board of Governors during the time of The War Game. As Sir Norman Brook, Cabinet Secretary to the Atlee, Churchill, Eden and Macmillan Governments, he had been the Cabinet Office's chief war planner between 1947 and 1962, modelling scenarios and leading covert preparations should there ever be a nuclear attack on the UK. His name features extensively throughout the pages of Peter Hennessy's well-known study, The Secret State, in which Hennessy used declassified papers 
to reveal how the British Government secretly prepared for the unthinkable. Calling him 'the great Whitehall technician' (2010: 277), Hennessy summarises Norman Brook as:

... The last man in Whitehall to have any illusions of what a nuclear attack on the UK might mean. Throughout the high Cold War, he briefed his four premiers - Atlee, Churchill, Eden and Macmillan - on the catastrophe that awaited the UK if global war came... He was the human fulcrum around which the 1954-5 rethinks took place in the shadow of the H-Bomb. He drove through the plans for pre- and post-attack.... (Hennessy, 2010: 154)

This was now the very same man confronted with helping to decide the fate of a film that deliberately set out to reveal on national television to a mass audience many of the harrowing facts of life in a post-nuclear attack Britain which he personally had briefed Ministers about in top secret only a few years before.

As the Cabinet Office papers reveal, when Normanbrook and Greene agreed the decision to refer the film to Whitehall, they 'undoubtedly' assumed the conclusion reached by officials and Government Ministers would be 'that the film should not be shown'. ${ }^{22}$ They were testing the water with the current regime as to whether such a film could be shown to the public but were actively assuming the answer that would come back would be 'no'.

\section{The Wilson Game}

The subsequent course of events shows the pattern playing itself out in Whitehall largely as Normanbrook and Greene had expected, except the intervention of one highly prominent voice along the way meant the senior civil servants had to adjust the approach they took to dealing with this issue. The Cabinet Office files indicate that following its screening for officials at BBC 
Television Centre on Friday September 24, those officials met the next Monday, September 27, to discuss the film. The Cabinet Secretary, Sir Burke Trend, then prepared a draft submission which he circulated for comment round his colleagues from the various Ministries who had attended the screening with him. ${ }^{23}$ Marked 'SECRET', this is a revealing memo since it records officials' first reactions after seeing the film prior to any formal revision of opinion for Ministers. Quite clearly, it shows the primary objective for the civil servants was to try to come up with the most convincing reason for the film to be suppressed.

Thus Trend began:

1. Do we agree that by comparison with a good many other films of violence which are shown on television this is not a "horror" film to which we could take exception on grounds of public decency, etc. ?

2. If so, there seem to be only two broad grounds on which we could object - ie. a) that the film is inaccurate and misleading; or, b) that it would be politically inexpedient to show it publicly. ${ }^{24}$

Point 1 ) is highly significant in light of the $B B C^{\prime}$ s subsequent announcement to the press that the reason the film could not be shown on television was because it was too 'horrifying'. This, however, was not the initial reaction of the 'special people' the BBC had invited to see it and therefore not why, in their opinion, the film could not be broadcast.

Instead, the rest of Trend's draft concentrated on exploring whether there were any grounds under point 2) that could be used. Significantly, there was nothing in Trend's memo that stated there was anything 'inaccurate' in Watkins' depiction of a nuclear attack. As Matthew Grant has 
noted in his study of UK civil defence preparations during the Cold War: 'Had a nuclear war broken out on the scale depicted in the film, the British civil defence planners could only have hoped that their policies worked as well in reality as they did in The War Game' because 'the reality... would have been undoubtedly worse than that portrayed by Watkins' (2010: 187). Instead Trend focused on aspects that could be argued to be 'misleading' or 'unfair' in the film such as the buildup to the attack in which, in response to a growing international crisis, US President Lyndon Johnson orders nuclear retaliation. This, it was felt, ignored 'the politico/military effort' which would 'undoubtedly be made by the great Powers to prevent the type of escalation which the film portrays'. Also, notwithstanding the later historical conclusions of Grant, the film was '"unfair"', Trend wrote, in 'writing down so heavily the effectiveness of civil defence precautions and the ability of the population to cope with devastation on a tremendous scale' ${ }^{25}$

Trend then went on to reflect that even if the film were altered to meet such criticisms, might it still be possible for officials to advise their Ministers not to consent to its public showing on the grounds it would be politically inexpedient? This, however, was a tricky area:

If so, we should have to base ourselves on the even more arguable ground that the film would be liable to cause unnecessary and undesirable alarm and despondency and to touch off a renewed public argument on the issues of the independent nuclear deterrent, the CND campaign etc., which the Government would find inopportune at this (? [sic.] or any other) point of time. This could be a difficult and embarrassing argument to sustain...

Trend ended his draft with the conclusion that 'the right balance between these conflicting considerations is very much a matter of political judgment - i.e. it is for Ministers to strike'. And he added: 
It is complicated at this juncture by the fact that the Government are engaged in a review of civil defence policy, the results of which will have to be announced fairly soon - and may be difficult enough to sell to public opinion (including our NATO allies) without further complications of the type which the film might create. ${ }^{26}$

In February 1965, the recently elected Labour Government under Harold Wilson had ordered a review of existing civil defence policy. The reasons were clear. Having inherited a balance of payments crisis, the Government needed to make savings in the civil defence budget. It was pouring considerable resources into preparing for a future event everyone fervently hoped would never happen. By the time the results of the review were outlined in Parliament in February 1966, reductions in expenditure had been recommended, together with an axing of the rescue and lifesaving functions of the voluntary Civil Defence Corps. By January 1968, the Corps itself had gone, meaning home defence preparation had been cut down to a minimum 'care-and-maintenance' basis (Grant 2010: 182-8).

The War Game's portrayal of how inadequate existing UK civil defence preparation would be in the face of thermonuclear war was in fact a reality the Government was facing up to and acknowledging internally at that very moment. Yet in a supreme irony, if such a film were to be shown on television in late 1965, it might potentially have made it more difficult, not less, for the Government to push through the cuts to civil defence it felt were needed, despite it being in effective tacit agreement with Watkins that nuclear war was essentially unsurvivable. Rather than cries of ban the Bomb, there might have been howls the film had exposed existing preparations as so woeful the civil defence budget had to be increased massively to protect the public - not what the Labour Government wanted, or needed, at this time, as Trend recognised. 
By 6 October, Trend had submitted a final agreed draft to the Lord President Herbert Bowden who a month before had discussed The War Game with Greene and Normanbrook over lunch. Trend's Private Secretary, McIndoe, drew his superior's attention to an article from the Daily Mail, dated 28 September, indicating that Watkins had now resigned from the BBC: 'I think that on the whole this should make it easier for the BBC to suppress the film (since the man has already resigned without a decision being taken), if the decision goes that way'. ${ }^{27}$ In his submission to Bowden, Trend iterated that the implications of showing the film to the public were so 'highly political' that 'Ministers should see the film themselves'. He then went on to outline, as in his earlier draft, the aspects where the film could be open to criticism, including the opening build-up to the attack which was a 'negation of the theory of deterrence' and the 'pessimistic impression' given of Civil Defence. Trend ended by reminding Bowden that Normanbrook and Greene had indicated to him that if on grounds of 'public policy' the film should not be shown, the BBC might be prepared to issue a statement that it had taken the decision on its own, though Trend noted this could not be taken for granted: 'The difficulty, for the BBC no less than for the Government, is to think of some reason for suppressing the film which would not stir up controversy or provoke suspicion that it was motivated by political prejudice, whether of the pro- or anti-CND type' ${ }^{28}$

At Bowden's request, Trend forwarded his submission to Harold Wilson with a view to the Prime Minister's opinion being sought and on 12 October 1965, the PM himself became involved, meeting both men. Wilson's reaction was different, however, from Trend's advice and perhaps Trend's expectation - the Prime Minister did not want his Ministers to preview the film for approval. As Wilson's Principal Private Secretary, Derek Mitchell, confirmed to Trend in a Downing Street memo following that day's meeting: 'It was agreed that you should indicate to Lord Normanbrook that HMG, as a Government, did not wish to offer any view on whether or not the 
film should be shown to the public'. Instead it was suggested to Trend that he might offer to arrange for Lord Normanbrook to 'hear privately' the views of Trend and the Permanent UnderSecretaries of State for the Home Office and the Ministry of Defence and that 'in addition you should suggest ways of presenting the film which would put its controversial aspects into perspective'. For example, Mitchell's memo continued, the film might be followed by a discussion in the course of which 'balanced comment' could be given on it. Mitchell's memo from the PM ended: 'This comment would be bound to have a political character but need not be blatantly so if the right people were chosen' ${ }^{29}$

Thus while Normanbrook as BBC Chair had felt the film 'ought to be looked at' by the Government and Trend as Cabinet Secretary had assumed judgment on it was one for Ministers to strike, Wilson took a different approach, distancing his Government from any direct involvement in intervening in a BBC film and leaving it instead to the civil servants to deal with and ultimately to the Corporation itself. Wilson was drawing a careful distinction between 'Government' comprising elected Ministers of the Crown and 'Whitehall' as the machinery of state operated by civil servants. The film had been brought by Normanbrook and Greene to the attention of both Whitehall civil servants and Government Ministers but Wilson was now trying to put some distance between it and the latter, no doubt sensing the political dangers - and a possible political trap for Labour - should there ever be exposure of Government involvement in direct censorship of the BBC.

Does this mean Wilson was supportive of showing the film on television, albeit framed by a discussion involving the 'right people' ? A Home Office memo sent to Trend the next day, 13 October, provides further insight into the direction of Labour Government thinking on The War Game. Sir Charles Cunningham, Permanent Under-Secretary of State at the Home Office, had 
been one of the officials invited along with Trend to view the film at the BBC on 24 September. In common with the majority of the other officials who had attended that day, he had offered no comments on Trend's draft before it was submitted to Bowden, only indicating that once Trend had submitted to Bowden to let him know as 'I would like to let the Home Secretary know how this matter stands'. ${ }^{30}$ The day after Wilson had advised Trend and Bowden, however, Cunningham wrote back with the response of the Home Secretary, Frank Soskice, to the film.

Cunningham wrote that the Home Secretary recognised there were two main questions involved: 1) whether in view of its contents and 'horror scenes' the film was suitable for public showing and 2) 'whether it would be right for the Government to take steps to discourage the BBC from showing it' ? As to the first question, Cunningham stated 'the Home Secretary's personal view would be against the showing of the film'. However, Soskice realised the critical question was the second and 'his present feeling' was that 'the decision must be left to the $B B C$ ' since 'the Government would put itself in an extremely difficult position if it could be said that it had either forbidden the showing of the film or used its influence to discourage it' ${ }^{31}$

'Present feeling' suggests that the Home Secretary had originally thought the film should be banned outright but that he had shifted his position, recognising the political dangers for Government of a direct ban. Essentially, therefore, Soskice was echoing Wilson's advice and the fact this first formal statement of the Home Secretary's position came a day after Wilson's meeting with Trend does not seem coincidental in this respect, providing important clues as to how the Labour Government under Wilson had decided eventually this issue should be handled: namely, that there were other more subtle ways than the brute force of externally imposed censorship upon the BBC. 
Cunningham outlined for Trend Soskice's suggestion that 'a small group of Ministers should see the film - as unobtrusively as possible'. It might well then be possible 'to say to the BBC that the film is open to criticism on the grounds that the introduction is politically improbable and the presentation of the results of a nuclear exchange extremely partial and one-sided'. Ministers might go on to make it clear 'that the decision whether or not the film should be shown must be taken by the BBC itself and that the Corporation must accept full responsibility for it' $^{32}$

Here is what one might call 'The Wilson Game' - a more sophisticated and subtle approach than a direct Government ban imposed by Ministers and entirely characteristic of a Prime Minister famous for his political guile. Normanbrook - the ex-Whitehall mandarin, ever mindful of his responsibilities to 'public policy'33 - had brought an issue of potential embarrassment and political difficulty to the Government should the latter be seen to be involved. The Government realised, however, that it need not be explicitly involved for it still to have powerful influence and effect over the final decision. Views could be communicated that the film was 'unbalanced' in certain aspects and the $\mathrm{BBC}$ then told it was its decision whether or not to show the film but that it must take 'full responsibility' for any consequences. Against a background of ongoing hostility between the Labour Party and BBC that autumn fuelled by Wilson's suspicions of Corporation bias against him - there had been complaints about the BBC's coverage of the Labour Party conference; plus Herbert Bowden was chairing a powerful Ministerial Committee on Broadcasting looking at the whole question of whether the BBC should carry advertising on certain services as a means of resourcing the expansion of broadcasting ${ }^{34}$ - such a message, or perhaps warning, regarding 'full responsibility' would have carried considerable import.

Apart from the substitution of Ministers by civil servants, this is essentially the approach that was then taken in terms of communicating back to the BBC on The War Game. Wilson had a strong 
admiration and trust of the Civil Service and leaving the job entirely to senior civil servants meant Ministers did not have to be seen to be involved in any way at all. ${ }^{35}$ On Friday 5 November at 9.45am, Trend and Cunningham, along with Alan Wolstencroft (Deputy Director-General of the Post Office) who had all attended the 24 September screening, met with Normanbrook in Trend's room at the Cabinet Office. In contrast to Trend's previous more discursive memos for Government and Whitehall colleagues on the pros and cons of suppressing the film, the record of this meeting is much more concise and essentially a summary of the positions of each side, suggesting the civil servants now had clear direction on how to deal with this.

Thus Trend began the meeting by stating that although it was known to certain members of BBC staff a small group of civil servants had seen the film: 'Her Majesty's Government had decided that they did not wish, as a Government, to offer any view to the $B B C^{\prime}$ on whether the film should be shown to the public. Trend went on to make clear that Ministers themselves had not seen the film. He then outlined for Normanbrook that the film had two main defects. These were, of course, 'views' but ones now being attributed to senior civil servants, not the Government. They were the ones which Trend had already highlighted in earlier memos to fellow civil servants and Ministers - namely, the presentation of the build-up to nuclear war which 'omitted the whole range of Government action that would be taken to avert such a tragedy' and the fact the American President was not shown 'in a very creditable role'. The second main defect, Trend outlined, was that 'the film depicted our civil defence forces in complete disarray as a result of a nuclear explosion'. Following Wilson's advice, Trend ended that the BBC might therefore wish to consider, if they decided to show the film to the public, 'whether to amend the film in any way or else to show it in the context of a responsible, preferably a-political [sic.] discussion' ${ }^{36}$

For his part, Lord Normanbrook responded that 'if a decision were taken by the BBC to show the 
film', most of 'the responsible opinion in the BBC would be in favour of showing it in a context of a reasoned discussion'. ${ }^{37}$ By 'responsible opinion', Normanbrook was most likely reflecting the views of senior BBC management such as Director of Television Kenneth Adam and Controller of Programmes Huw Wheldon who had argued for the programme to be made in the first place, despite the earlier expressed doubts of both himself and Greene. ${ }^{38}$ Normanbrook, however, stated to the meeting that his own 'personal view was that it was a film that should not be shown' although he did acknowledge that the 'producer of the film' could argue that 'the general public ought to have brought home to them an imaginative picture of the effect of a nuclear explosion'. Finally, Normanbrook noted 'the producer', Watkins, was on the point of leaving the BBC and the fact that the film had been made was 'now public knowledge'. ${ }^{39}$

After discussion, it was agreed Lord Normanbrook would take 'further soundings' within the BBC and inform the Cabinet Secretary 'of the terms in which the BBC would announce their decision about whether or not to show The War Game'. Normanbrook stated it was possible that the BBC would say 'that they had taken their decision after consultation with the Government'. In the meantime, if there were Parliamentary Questions (which clearly both sides were anticipating now that the film was public knowledge), 'the Government might say that, while Ministers had not seen the film, officials had and that while the Government had offered no advice to, or exerted pressure on the BBC, they had caused their views on the presentation of the film to be conveyed to the $\mathrm{BBC}^{\prime}$. $^{40}$

Here is confirmation that Normanbrook personally did not want the film to be shown, notwithstanding the views of other 'responsible opinion' within the BBC. Also there is an indication the $\mathrm{BBC}$ might say it had taken its decision 'in consultation with the Government'; an interpretation which the civil servants qualify for their part as being the views of officials 'on the 
presentation of the film'. This recorded difference may possibly betray an initial irritation on Normanbrook's part that a decision he had expected the Government to take had been thrown back by the Wilson Government onto the BBC. Normanbrook and Greene may have hoped by referring it to Government that ultimate responsibility for the decision over whether or not to show The War Game might have been taken from them, but now here it was being bounced back by the Wilson Government on to the BBC and Normanbrook and Greene's shoulders. Yet as Normanbrook pointedly recorded in his own personal account of this meeting for Greene: 'Whitehall will be relieved if the BBC decides not to show it'. ${ }^{41}$ Not only was this a form of pressure on Greene to (continue to) side with Normanbrook's personal view that the film should not be shown, it also probably was a quite accurate reflection of the sense the Chairman had taken away from talking to his former colleagues in Whitehall: to mandarins like Trend who, more than any mere politicians of the day, were the long-term guardians of the British Cold War state and who, as the record shows, had originally assumed the political decision over whether to ban The War Game was one Ministers would take directly themselves.

Between 5 November and the BBC's press announcement of the TV ban on 26 November, we enter the period of silence in terms of the written record which Tracey and other scholars have noted with frustration (Tracey, 1982: 52; Shaw, 2006: 1371). There is no surviving, or at least extant, written record within the BBC archive as to who banned The War Game; no 'killer memo' from Greene or Normanbrook explicitly authorising the ban. Instead, there is just a short press release at the end of the month that the $\mathrm{BBC}$ had decided not to show the film 'after a good deal of thought and discussion, but not as a result of outside pressure of any kind' ${ }^{42}$ Consulting the Cabinet Office record provides, however, a fresh trail of evidence, new clues and a new theory. 
which emerged shortly after the 5 November meeting broke up. That afternoon it became known that The War Game was likely to be the subject of an article in The Sunday Times later that month 'inspired by Peter Watkins'. ${ }^{43}$ Watkins, resigned now from the BBC and fearing his film was being indefinitely shelved with no decision on it needing to be communicated to him by the $\mathrm{BBC}$, had taken his case to the newspapers, revealing that 'non-BBC personnel' from the 'Home Office' (he did not know exactly who at that stage) had viewed the film on 24 September. ${ }^{44}$ This prompted close collaboration between the $\mathrm{BBC}$ and Whitehall to agree a common line to answer press queries with a view to minimising any damage. ${ }^{45}$

The Sunday Times article, 'Whitehall disliked a nuclear film', duly appeared on 14 November and thus it may well have made sense for the BBC to wait in order to deal with anything that Watkins might say to the press and also until the timing for its own announcement was better. In the wake of the article, the BBC announced it would decide 'within the next fortnight' whether or not to show The War Game. ${ }^{46}$ At that point, mid-November, Greene was away at a European Broadcasting Union conference in Germany (Tracey, 1982: 53) but on his return, told a meeting of the BBC's Board of Management on Monday 22 November that a decision was 'imminent' and that Kenneth Adam had already drafted a statement for the Chairman (Tracey, 1982: 52). On 24 November, Normanbrook wrote to Trend informing him that the $\mathrm{BBC}$ would not be showing The War Game and enclosing a copy of the press statement, which was duly released to the public on Friday 26 November.

The Sunday Times article and the timing of Greene's German trip may have delayed the release of the press statement but the reason there is no actual extant written record within the BBC authorising the banning may simply be, from the evidence, because there was no need for any further formal meetings or correspondence between Normanbrook and Greene on this, following 
Normanbrook's report to Greene of his Cabinet Office meeting of 5 November. Both

Normanbrook and Greene, in a sense, had already pre-agreed the non-showing of The War Game as a fait accompli when they had referred the film to Government. They had assumed the Government would say it could not be shown on TV and that the BBC would then put out a press statement, as it had offered, saying this was a decision it had taken on its own. The only complication to the predicted pattern was when Wilson refused to allow the Government to be explicitly linked to the censorship, instead pressuring the BBC to take the decision on its own with 'full responsibility' for any consequences. While Wilson's motives may remain open to question not least regarding his personal relationship with the BBC, what he did succeed in doing, however, was giving both Government and Corporation an 'out' whereby each could deny any collusion with the other despite the fact the reality was far less clear-cut. By this means, the Government was able to achieve maximum distance and deniability of having had any involvement in the decision over The War Game even though the true picture, as we can now see from the Cabinet Office papers, was actually a much more complex one of contact and collaboration throughout between Ministers in Government, senior civil servants in Whitehall and those at the very top of the BBC.

\section{Conclusion: 'Fall-out'}

Thus in answering, fifty years later, the question of 'Who banned The War Game ?' it can be seen many hands were involved. There was a complex dance between Normanbrook and Greene at the very top of the BBC; Normanbrook's senior ex-colleagues in Whitehall and behind them, Ministers in the Labour Government of Harold Wilson, including the Prime Minister himself. As Goodwin (2005) has documented, in 1955, the Conservative Government of Sir Winston Churchill threatened the BBC with an explicit veto of any programmes which did not comply with 'public policy' - namely, not to broadcast too graphic depictions of the effects of nuclear weapons for fear of panicking or demoralising the public in the Cold War. ${ }^{47}$ By 1965 , however, things were 
handled more subtly under the direction of the new, politically guileful Labour Prime Minister Harold Wilson. This may have initially surprised the expectations of old Civil Service colleagues like Normanbrook and Trend, accustomed to the Conservative Governments of the 1950s, but in the end the results of the interaction between the Corporation and the Government effectively amounted to the same. Censorship is at its most naked and visible when it is external and imposed from without but can often be more pervasive and effective when internalised, meaning conditions operate that cause institutional actors to fall into line of their own accord without the need for potentially embarrassing direct action by the governing power itself. For Goodwin, briefly comparing the 1955 Government directive with The War Game furore of ten years later, what both have in common is an 'intervention by the core of the state in the day-to-day affairs of the BBC, which is denied by official myth' (Goodwin, 2005: 117).

Fifty years on, we need to be clearer-eyed about some of these official myths, peering behind them to uncover the more complex historical realities out of which they were formed as much, perhaps, to obscure as to enlighten. We need to reassess the wholesale acceptance of the myth of Hugh Greene, which was partly cultivated by himself during and after he left office, as the great liberalising Director-General; instead seeing a more complex, contradictory and in fact much more fascinating character: a product of the Cold War as much as of the 1960s and a Director-General who would pragmatically go along with censorship of particular programmes in order to avoid the public 'embarrassment' of splits between programme-makers and the BBC Board of Governors as he tried to navigate the Corporation as smoothly as possible through the more liberal 1960s and compete more effectively with ITV for the mass television audience. ${ }^{48}$ Above all, we need to be clear-eyed on the limits that there were and perhaps still are to the BBC's much-vaunted independence from Government. We need to recognise that throughout most of the early years of the Cold War, the BBC was still penetrated by the ethos and indeed numerous of the former 
personnel of Whitehall, with some of the most senior appointments within the Corporation being filled in those years by ex-senior civil servants or by those with a military, intelligence or anticommunist propaganda background. And as recent events have reminded us, with concerns about 'backroom deals' and the Corporation coming under various pressures from the incumbent administration without proper public scrutiny or consultation, the question of what is the true extent of the BBC's independence from Government still remains very much a live one. ${ }^{49}$ In this regard, The War Game offers a very interesting historical case study.

\section{Notes}

1. $39^{\text {th }}$ Academy Awards, Hollywood, 10 April 1967. For details of how the film gained a limited cinema release, see Cook and Murphy (2000) and Shaw (2006).

2. BBC Press Office announcement on The War Game, 26 November 1965, BBC WAC $\mathrm{T} 16 / 679 / 1$

3. At the time, Watkins denied he had resigned directly because of The War Game but rather 'to join actor Albert Finney's new film-producing company, Memorial Enterprises'. (Daily Mail, 28 September 1965)

4. Michael Tracey, 'A nightmare vision that shook the BBC', The Guardian, 1 September 1980, p.12.

5. Hugh Greene, 'The decision to kill The War Game was mine alone: Letters to the Editor', The Guardian, 4 September 1980, p.10.

6. Archive on 4: The War Game Files, tx. BBC Radio 4, 6 June 2015. Written and produced by David Morley (A Bite Media production for Radio 4).

7. Chapman's article, which was partly a response to Murphy, contested the 'conspiracy' view by arguing the censorship of the film was largely a BBC internal decision, however this attracted its own controversy when Mike Wayne received a right of response in the same 
journal accusing Chapman of 'failing the public' through an 'essentially apologetic defence of a public broadcaster's unhealthily close ties to the state' (Wayne, 2007: 627). If nothing else, the spat illustrated how controversial The War Game debate remains, even decades on. The most comprehensive account to date is arguably Shaw's which draws upon a range of archival sources to examine not only the censorship but the production and the after-life of the film following its 1965 banning from TV.

8. Other folders related to The War Game include Home Office files on the civil defence implications of The War Game (TNA HO322/203 and TNA HO303/22) and Foreign Office files on the question of overseas cinema screenings (TNA FO953/2426).

9. Anon., 'BBC's War Game film is "too gruesome to show"', Sunday Express, 5 September 1965.

10. Letter from Mrs Mary Whitehouse to Rt. Hon Harold Wilson MP, 6 September 1965, TNA CAB21/5808.

11. Derek Mitchell to Dennis Trevelyan, 7 September 1965, TNA CAB21/5808.

12. From 1956, Burke Trend had been Normanbrook's Deputy in the Cabinet Office, prior to being promoted to Cabinet Secretary himself on Normanbrook's retirement from the role in 1962. Hence this was the present Cabinet Secretary being approached by his trusted predecessor with whom he had worked closely for many years.

13. Bill Mclndoe to Dennis Trevelyan, 7 September 1965, TNA CAB21/5808.

14. Ibid..

15. Letter from Lord Normanbrook to Sir Burke Trend, 7 September 1965, TNA CAB21/5808.

16. The Lord President of Council is one of the Great Offices of State of the UK parliamentary system. The Lord President's role is normally to attend each meeting of the Privy Council, presenting business for the monarch's formal approval. In Governments of the post-war era, the Lord President frequently (though not always) has been the Leader of the House of 
Commons. The reason for the particular involvement of Herbert Bowden with Greene and Normanbrook was that Bowden had been put in charge by Harold Wilson of a powerful Ministerial committee which was looking at the whole future of broadcasting in the UK. Part of this involved considering whether the BBC should take advertising on its radio service, the Light Programme, as a means of financing the future expansion of broadcasting in lieu of any licence fee increase - a move Bowden (along with then Postmaster-General Tony Benn) championed but the BBC were readying to oppose. This would be why Greene and Normanbrook were in regular touch with Bowden during this period; why Bowden felt at liberty to raise the matter of The War Game with them and also provides a possible contextual explanation for why Greene and Normanbrook may have been particularly keen to be as diplomatic and as accommodating as possible to Government on controversial matters during this nervous period for the BBC. For further on Labour Government discussions and proposals around alternative financing of the BBC (proposals which were eventually shelved), see Briggs (1995: 536-46) and Freedman (2003: 50-55).

17. Dennis Trevelyan to Derek Mitchell, 8 September 1965, TNA CAB21/5808.

18. BBC Press Office announcement on The War Game, 26 November 1965, BBC WAC T16/679/1.

19. The phrase was first publicly articulated by the BBC's initial wartime Director-General, F.W. Ogilvie, in an interview for The Listener (28 August 1941, p.299).

20. Prior to this experience, Greene had served as a chief correspondent for the Daily Telegraph in Nazi Berlin before being expelled by the Nazis and working for RAF Intelligence at the outbreak of the Second World War. He then was invited to be Head of the BBC's radio service broadcasting Allied propaganda to Germany during the Second World War. Later in his career, he would become overall Director of News and Current Affairs at the BBC, prior to being appointed Director-General. The brother of novelist 
Graham Greene, in 1957 the pair edited together The Spy's Bedside Book - an anthology of writings on espionage techniques. For further on Greene's life, see Tracey (1983).

21. Indeed Greene is on record as saying he was more horrified by The War Game than Normanbrook when they first saw it and was dead-set against its public showing from the start (archive interview, The War Game Files, tx. BBC Radio 46 June 2015). Given Normanbrook's intimate knowledge of nuclear war scenarios, this may not be entirely implausible. Murphy quotes Chris Greene, Hugh Greene's son, that 'my father was bounced into the decision' (2003: 27) to ban the film by Normanbrook. However, this may be a retrospective effort by a son attempting to defend his father's liberal reputation from the challenge which the banning of The War Game inevitably poses to it.

22. Dennis Trevelyan to Derek Mitchell, 8 September 1965, TNA CAB21/5808.

23. Alongside Trend, these were Sir Charles Cunningham, Permanent Under-Secretary of State at the Home Office; Alan Wolstencroft, Deputy Director-General of the Post Office; George Leitch, Deputy Under-Secretary of State (Policy) at the Ministry of Defence and Brigadier A.C. Lewis representing the Joint Chiefs of Staff.

24. Sir Burke Trend, draft submission for Lord President of Council, 27 September 1965, TNA CAB21/5808.

25. Ibid..

26. Ibid..

27. Bill Mclndoe to Sir Burke Trend, 1 October 1965, TNA CAB21/5808.

28. Sir Burke Trend, final agreed submission for Herbert Bowden (Lord President of Council), 6 October 1965, TNA CAB21/5808.

29. Derek Mitchell to Sir Burke Trend, 12 October 1965, TNA CAB21/5808.

30. Sir Charles Cunningham to Sir Burke Trend, 1 October 1965, TNA CAB21/5808.

31. Sir Charles Cunningham to Sir Burke Trend, 13 October 1965, TNA CAB21/5808. 
32. Ibid..

33. Normanbrook, along with Greene, would have been cognisant of the BBC's Licence and Agreement with Government to broadcast (coterminous with the Royal Charter) in which Government retained formal reserve powers to veto particular broadcast programmes. At the most recent renewal of the BBC's Licence and Agreement in 1964, these reserve powers had been defined in Parliament as a Government ban 'on broadcasts by the BBC of its own opinions on current affairs or matters of public policy' together with unauthorised party political broadcasts (Hansard, $5^{\text {th }}$ Series, v. 647,47 ). Given its powerful questioning of then current UK civil defence and nuclear weapons strategy, The War Game could have been seen, in this narrow view, as potentially falling under the above definition of 'public policy' and therefore requiring referral to Government for a decision.

34. Wilson had personal animosity towards the $B B C$, consistently believing there was a 'BBC plot' against him. Things had come to a head in October 1965 when Wilson had attacked the BBC's coverage of the Labour Party's annual conference (Briggs, 1995: 553; Tracey, 1983: 268-9). For the potential imposition on the BBC at this time of advertising, see note 16. Hence there was a range of pressures from Government acting upon the BBC that autumn.

35. See Alan Watkins [1966] cited in Theakston (2004): Wilson 'displayed a profound reverence for the orders and mysteries of the civil service... He would be most upset if he ever thought he had caused serious offence to a permanent secretary' (Theakston, 2004: 2).

36. W.K. Reid (Secretary), 'Note of a meeting held in Sir Burke Trend's room, Cabinet Office', 5 November 1965, TNA CAB21/5808.

37. Ibid..

38. Greene and Normanbrook had originally wanted Watkins' film shelved at the script stage due to the 'weighty problems' involved but Wheldon had pushed hard for it to be made. 
Watkins had been recruited by Wheldon whilst he had been Head of Documentary Programmes and Wheldon was keen to retain Watkins' services following the success of the latter's debut BBC film, Culloden (tx. 15 December 1964). On this basis, Wheldon managed to win approval for The War Game on a stage by stage basis and Kenneth Adam supported him. This allowed the film to be produced but only on the proviso that Greene and Normanbrook would view The War Game at the assembly stage and decide its fate then. For further on the BBC internal process, see Tracey (1982), Chapman (2006) and Shaw (2006). Hence Greene and Normanbrook were faced with their most senior programme managers in the BBC Television Service supporting the film. In referring it to Whitehall, both men therefore were perhaps anticipating that Whitehall would provide the ultimate vindication of their original expressed doubts in ways that their senior programme staff would be unable to argue against.

39. W.K. Reid (Secretary), 'Note of a meeting held in Sir Burke Trend's room, Cabinet Office SW1 on Friday 5 November 1965 at 9.45am', 8 November 1965, TNA CAB21/5808.

40. Ibid.. Numerous Parliamentary Questions were indeed tabled over the ensuing weeks and months about the film's banning from TV. In each case, the Government denied any involvement with the decision over the film. For example, the Prime Minister Harold Wilson to the House of Commons on 30 November 1965: 'The Government have informed the BBC that we have no observations to make on whether it should be shown or not' (Hansard, $5^{\text {th }}$ Series, v. 721, 1229-1330).

41. Lord Normanbrook to Sir Hugh Greene, 5 November 1965, BBC WAC T/16/679/1.

42. BBC Press Office announcement on The War Game, 26 November 1965, BBC WAC T16/679/1.

43. W.K. Reid (Secretary), 'Note', 8 November 1965, TNA CAB21/5808.

44. Cal McCrystal, 'Whitehall disliked a nuclear film', Sunday Times, 14 November 1965 (press 
clipping), TNA CAB21/5808.

45. W.K. Reid (Secretary), 'Note', 8 November 1965, TNA CAB21/5808.

46. Anon., 'Decision soon on nuclear film', The Times, 18 November 1965, p.7.

47. As a result of this Government intervention, Director-General Sir lan Jacob drew up a policy paper for senior BBC executives entitled 'Thermo-nuclear weapons and broadcasting'. A planned radio programme on the $\mathrm{H}-\mathrm{Bomb}$ and planned contribution of a scientific critic of nuclear weapons, Joseph Rotblat, to a BBC TV Panorama programme were both dropped. Goodwin (2005) provides the important context for understanding the frequent references to 'public policy' which occurred in discussions around The War Game ten years later and of which Normanbrook would have been acutely aware since, in 1955, as Churchill's Cabinet Secretary, he had had leading involvement in Government discussions with the BBC over this very matter (Goodwin, 2005: 104).

48. For example, in a precedent of sorts to The War Game, Greene cancelled the popular satirical series That Was The Week That Was, which he had previously supported, in order to avoid a damaging split with the BBC Board of Governors. See Tracey (1983: 220).

49. Anon., "'Shabby deal" with Government outlined in which BBC will fund $f 650 m$ cost of TV licences for over-75s', Press Gazette, 6 July 2015, http://www.pressgazette.co.uk/shabbydeal-government-outlined-which-bbc-will-fund-\%C2\%A3650m-cost-tv-licences-over-75s, accessed 1 September 2015.

\section{References}

Briggs, Asa (1995), The History of Broadcasting in the United Kingdom Volume V: Competition, Oxford: Oxford University Press.

Chapman, James (2006), 'The BBC and the censorship of The War Game (1965), Journal of Contemporary History, 41:1, pp.75-94. 
Cook, John R. and Patrick Murphy (2000), 'After the bomb dropped: the cinema half-life of The War Game', Journal of Popular British Cinema, 3, pp.129-132.

Freedman, Des (2003), Television Policies of The Labour Party 1951-2001, London: Frank Cass Publishers.

Goodwin, Peter (2005), 'Low conspiracy ? - Government interference in the BBC', Westminster Papers in Communication and Culture, 2:1, pp.96-118.

Grant, Matthew (2010), After The Bomb: Civil Defence and Nuclear War in Britain 1945-68, London: Palgrave Macmillan.

Greene, Hugh Carleton (1950), 'Through the iron curtain', BBC Year Book 1951, London: British Broadcasting Corporation, pp.11-14.

Hennessy, Peter (2010), The Secret State: Preparing for the Worst 1945-2010, London: Penguin Books.

Miall, Leonard (1994), Inside the BBC: British Broadcasting Characters, London: Weidenfeld and Nicholson.

Murphy, Patrick (2003), 'The War Game - the controversy', Film International, 3, pp.25-8.

Nelson, Michael (1997), War of the Black Heavens: The Battles of Western Broadcasting in the Cold War, New York: Syracuse University Press.

Shaw, Tony (2006), 'The BBC, the state and Cold War culture: the case of television's The War Game (1965), English Historical Review, 121:494, December, pp.1351-84.

Theakston, Kevin (2004), 'The 1964-70 Labour Governments and Whitehall Reform', POLIS Working Paper, 2, February, pp.1-26.

Tracey, Michael (1982), 'Censored: The War Game story', in Crispin Aubrey (ed.), Nukespeak: The Media and The Bomb, London: Comedia Publishing Group, pp.38-54.

Tracey, Michael (1983), A Variety of Lives: A Biography of Sir Hugh Greene, London: The Bodley Head. 
Wayne, Mike (2007), 'Failing the public: the BBC, The War Game and revisionist history: a reply to James Chapman', Journal of Contemporary History, 42:4, pp.627-37.

Webb, Alban (2014), London Calling: Britain, the BBC World Service and The Cold War, London:

Bloomsbury Academic. 